\title{
Haralds Voskis, habilitētais medicīnas doktors, profesors
} (1928-2011)

2011. gada vasarā piepeši mūžībā aizgāja ilggadējs Medicīnas vēstures muzeja draugs, ķirurgs, anatoms Dr. habil. med. Haralds Voskis.

H. Voskis dzimis 1928. gada 19. janvārī, Rīgas Medicīnas institūta (RMI) Medicinnas fakultāti beidzis 1953. gadā. Jau studiju gados viņš aizrāvās ar ķirurǵiju, bija profesora Aleksandra Bieziņa asistents. Tiešāā saikne ar tik izcilu ķirurgu un medicīnas vēstures pazinēju kā profesoru Bieziņu bija tā auglīgā augsne, kas izveidoja tik neordināru personību kā H. Voskis.

1958. gadā viņš aizstāvēja kandidāta disertāciju par tēmu "Gūžas locītavas operatīvo pieeju novērtējums”, ko monogrāfijas veidā krievu valodā iespieda Maskavā.

1973. gadā viņš kḷuva par Operatīvās ķirurǵijas un topogrāfiskās anatomijas katedras vadītāju. 1975. gadā kopā ar kolēgeēm Ainu Mansoni un Veltu Timermani H. Voskis izdeva pirmo mācību grāmatu topogrāfiskajā anatomijā latviešu valodā. Vēlāk kopā ar A. Mansoni un sadarbībā ar neiropatologiem un neiroķirurgiem pievērsās pētījumiem perifēro nervu kompresijas lokalizācijā un kompresijas iemeslu noskaidrošanā ekstremitātēs.

Doktora disertācijas darba gaitā - jau sadarbībā ar Traumatoloǵijas un ortopēdijas zinātniski pētnieciskā institūta bērnu ortopēdiem un Republikāniskās Bērnu klīniskās slimnīcas rentgenologiem - H. Voskis izstrādāja vairākus oriǵinālus rentgenanatomiskos kritērijus gūžas locītavas displāzijas diagnostikā bērniem.

1984. gadā profesora A. Bieziņa vadībā H. Voskis aizstāvēja doktora disertāciju, 1986. kḷuva par profesoru. Kā atzinība par ieguldīto darbu 1997. gadā tika saņemta A. Bieziņa balva. 1999. gadā-Dr. habil. med. un visbeidzot 2008. gadā - H. Voskis kḷuva par Latvijas Ārstu biedrības goda biedru. 
1990. gadā H. Voski uzaicināja vadīit Anatomijas katedru, no kuras 1995. gada 30. jūnijā viņš svinīgi tika aizvadīts pensijā. Tā pavēra iespēju iedziḷināties arī medicīnas vēsturē un apkopot atmiņas par saviem skolotājiem un priekšgājējiem. Ar dziḷu pietāti un emocionalitāti viņš uzrakstīja atmiņas par profesoru Jēkabu Alksni, ievijot tajās daudz no A. Bieziṇa dzirdētā un paša pieredzētā. Fundamentāls ir viņa pētījums par Topogrāfiskās anatomijas un operatīvās ķirurğijas kursa un katedras vēsturi, publicēts LU Rakstos 2005. gadā. Viņš bija neaizstājams viesis un runātājs gandrīz visos Paula Stradiņa Medicīnas vēstures muzeja pasākumos.

Pēkšņā nāve pārtrauca šo sadarbību. Ir skumji un žēl, taču H. Voska padarīto var vērtēt tiem pašiem vārdiem, ko viņš novēlēja J. Alksnim: "Tava alga ir Tavi darbi savas tautas un tēvijas labā".

Rita Grāvere, Dr. hist.

Paula Stradiṇa Medicīnas vēstures muzejs

rita_gravere@inbox.lv 